Asian Review of Social Sciences

ISSN: 2249-6319 Vol.7 No.1, 2018, pp. 60-66,

(C) The Research Publication, www.trp.org.in

\title{
Service Quality and Customer Loyalty: A Study in Telecom Sector
}

\author{
Mubashir Majid Baba \\ Research Scholar, Department of Management Studies, University of Kashmir, Jammu and Kashmir, India \\ E-Mail: mubashirbaba.scholar@kashmiruniversity.net
}

\begin{abstract}
The objective of this paper is to study the impact of service quality gaps with customer loyalty in the Indian telecom sector. Service quality gaps has been considered as independent variable whereas customer loyalty was considered as dependent variable. Five antecedents of service quality gaps have been considered in this study viz. reliabilty, assurance, tangibility, empathy and responsiveness based on SERVQUAL model as given by Parsuraman, Zeithaml and Berry(1988). A survey-based exploratory and causal research design was used. A 27 items instrument was generated comprising of 22 items for the five antecedents of independent variables on the basis of the work of Parsuraman, Zeithaml and Berry(1988), and 5 items for customer loyalty on the basis of the work of Kaur and Soch (2012). The data was collected from 163 customers using mobile service of two telecom operators of J\&K (BSNL and Airtel) through structured questionnaires. Cronbach's coefficient alpha was used to determine the reliability of the instrument. Multiple regression analysis was used to determine the causal relationship between both the independent \& dependent variable. Results depicted that the service quality gaps has significant and positive impact on customer loyalty. The study suggests that the service providers should put their endeavor to upgrade the technology and serve the customers with modern equipments.

Keywords: Service quality, Customer loyalty, Telecommunication, Customer's perception, Service expectation
\end{abstract}

\section{INTRODUCTION}

There is wider scope and potential of growth of the services in the developing country like India. The Indian telecommunication sector is the second largest in the world after China. In this Scenario, if service providers would not put their endeavor in differentiating them from competitors, customers are more prone to switch to other competitor at almost zero cost. Services are deeds, processes and performances (Zeithaml and Bitner, 2003). Broadly speaking, "services are economic activities that creates value and provide benefits for customers at specific times and places as a result of bringing about a desired change in or behalf of the recipient of the services" (Christopher Lovelock, 1983). Success of a service provider depends on the high quality relationship with customers (Panda, 2003) who determine customer satisfaction and loyalty Lymperopoulos et al. (2006). For service marketing, service quality is an essential plank (Kushwah and Bhargava, 2014). Building long term relationship becomes a necessity today due to fierce competition in the market and hence customer loyalty is a growing concern of today. Indian Telecom industry has undergone a transformation change in past decade especially after the concept of privatization and strongly felt the need of customer loyalty. This need was felt due to availability of enormous number of market players in India. This stiff competition has compelled the service provider to compete in the market and to differentiate themselves on the basis of a factor other than price. Hence, this very concept of service quality has arises and gained attention. Better service quality provides competitive advantage to the organization. Any service organization can differentiate itself by providing high quality service.

The present study aims to evaluate the expectations and perception in telecom sector in the context of customer service quality. Organizations' primary emphasis of both academic and managerial efforts are focused on determining what service quality meant to customers and developing strategies to meet customer expectations (Parasuraman, Zeithaml, and Berry 1985, 1988). To put it other way, the success of service marketing depends upon the manner, the activities of external marketing have been carried out. The success of external marketing, itself depends how well the organization has been able to identify the customers' requirements and has carried its programs in the light of market orientation philosophy. Therefore, the success external marketing helps organizations understand customers' expectations and consequently offer in the light of the understanding. This results in least performance expectations gap and consequent desired customer loyalty. Therefore, the expectation $\mathrm{v} / \mathrm{s}$ perception and resultant gap was examined around the components of service quality.

Hence, this study is an attempt to analyze the impact of service quality gaps on loyalty with the focus on Gap 5 and attract the attention of practitioners towards betterment of service quality to reduce the customer attrition, and to give suggestions to improve the service quality. The results of the study help to determine the aspect of service quality gaps (reliability, assurance, tangibility, empathy and responsiveness) to be focused while formulating strategies to retain the loyal customers.

\section{REVIEW OF LITERATURE}

The service sector has been contributing tremendously for the growth of world economy. The sector has been main engine of the developed countries, as it contributes substantially towards their GDP sector. Service quality, one of the significant antecedents of customer satisfaction, exerts stronger influence on customer satisfaction and consequent purchase intention purchase intention (J. Joseph 
Cronin, Jr. and Steven A. Taylor, 1992). Gronroos (1982) defined service quality as "The result of an evaluation process where the consumer compares his expectations with the service he perceived he has received". In general, perceived service is compared to expected service. When one views the different definitions of this construct, the type of expectations used in its assessment has been the most unique characteristics (Parasuraman et al., 1991). Services are economic actions accessible by one party to another. Often time based, performances bring about desired results to recipients, items, or other resources for which purchases have accountability (Zeithaml et al., 1988).

\section{A. Service Quality Gaps}

Customer satisfaction arises from the discrepancies between prior expectations and actual performance of the product .As the perceived quality of service is the antecedent to determine customer satisfaction, it can also be interpreted as a measure of how well the service level delivered actually matches the customer's expectation (Gronroos, 1982). Following this line of thinking, Parsuraman, Zeithaml and Berry (1985) further elaborated this concept with a G ap Model which embraces a set of five gaps existing in the process regarding the management perception of service quality desired by customers and the service tasks required to deliver such an expected service to them. These gaps, as identified by Parsuraman, Zeithaml a nd Berry (1985), include:

Gap 1: The difference between customer expectations and management perceptions of customer expectations.

Gap 2: The difference between management perceptions of customer expectations and service quality specifications.

Gap 3: The difference between service quality specifications and the service actually delivered.

Gap 4: The difference between service delivery and what is communicated about the service to customers.

Gap 5: The discrepancy between customers' expectations on the service and their perceptions of the service performance. Amongst these gaps, gap 5 would be a function of the other four gaps.

\section{B. Service Quality}

Service quality has received a major amount of consideration by both researchers and practitioners. It has been distinct as at ypeof at hought related but not comparable to satisfaction that fallout from the association of expected service levels with perceived performance (Bolton and Drew,1992; Parasuraman et al., 1988; Cronin and Taylor, 1992). Modern marketing research in relation to customers' attitudes toward services has paying attention on perceived service quality. Perceived service quality is defined as the customer's assessment of the overall brilliance or authority of the service (Zeithaml 1988). Parasuraman, Zeithaml and Berry $(1985,1988)$ reflect on that a customer's assessment of overall service quality depends on the gap connecting expectations and perceptions of tangible performance levels. They intend that in general service quality is evaluated on five primary dimensions: tangibles reliability, responsiveness, assurance, and empathy. They suggest that each quality dimension can be quantified by obtaining procedures of expectations and perceptions of performance levels for service attributes related to each dimension, calculating the distinction between expectations and perceptions of actual performance on these attributes, and then averaging transversely attributes. They furthermore suggest that expectations should be influenced by individual needs, word-of-mouth announcement, and past experiences. Zeithaml, Parauraman and Berry (1985) perceived service quality is postulated to be subjective by the gap linking expectations and perceptions of performance (i.e., disconfirmation). However, the literature suggests a more elaborate copy in which disconfirmation, expectations, and actual performance levels influence customer satisfaction, which, in turn, becomes a key to customers' perceptions of service quality. Service quality measurement is significant as it has the possible to present insights into areas of service quality strengths and weaknesses.

Zeithaml, Berry and Parasuraman (1988) have developed and tested a strong evaluate of service quality, referred to as SERVQUAL. SERVQUAL is a 22 item scale consisting of five dimensions: reliability, responsiveness, assurance, empathy, and tangibles. Measuring customer "expectations" and "perceptions" of these five dimensions assesses service quality. Service quality is positively disconfirmed when customer perceptions exceed expectations.

SERVQUAL can serve as an effective indicative tool to direct management in its service quality perfection efforts by focusing awareness in the areas that are most needful (Berry et al., 1994). Service quality dimensions positively affect loyalty (Alnsour et al., 2014). SERVQUAL is an interpreter of customer satisfaction and Customer Loyalty with three out of the six quality dimensions of the chosen instrument and network quality dimension has a positive effect on customer satisfaction (Santouridis and Trivellas, 2010).

\section{Service Quality Dimensions}

Research suggests that customers do not perceive quality in a uni-dimensional way but rather judge quality based on multiple factors. The dimensions of service quality have been identified through the pioneering research of Parasuraman, Zeithaml and Leonard Berry. Their research identified five specific dimensions of service quality that apply across a variety of service contexts. Customer service, pricing structure and billing systems are the service quality dimensions which have more significant positive effect on customer satisfaction which in turn affects customer loyalty (Santouridis and Trivellas, 2010).Among the dimensions of service quality customer service and system reliability is most influential on perceived value and customer satisfaction and the influence of "content quality" ranks 
second (Ying- Feng Kuo et al., 2009).. Some studies have revealed that three dimensions (tangibles, empathy and assurance in SERVPERF did affect the level of customer satisfaction even though relationships were weak (Tung Lai Lai,2004).

1. Reliability: Ability to perform the promised service dependably and accurately. Reliability has a p ositive effect on customer loyalty (i.e., to perform the promised service) dependably and accurately (Alnsour et al., 2014).

2. Assurance: Employee's knowledge and courtesy of employees and their ability to inspire trust and confidence.Ability to convey trust and confidence. Service providers are expected to be the experts of the service they are delivering.

3. Tangibles: Appearance of physical facilities, equipment, personnel, and written materials. Tangibility was found to positively affect customer loyalty. The quality of being discernible by touch (Alnsour et al., 2014).

4. Empathy: Caring, individualized attention given to customers. Empathy was found to positively affect customer loyalty (Alnsour et al., 2014).Some recent studies have shown a post-adhoc analysis of telecommunication industry received excellent ratings o tangibles, particularly customer service and lower rating on empathy particularly service providers. Tangibles are an aspect of service quality. Service delivery systems should create positive moments of truth by ensuring that customer's point of contact is reduced to minimum (Johnson and Sirikit, (2002).

5. Responsiveness: Willingness to help customers and provide prompt service. Some research studies have argued that using gap analysis, service quality is found among this dimension along with responsiveness dimension, communication dimension, discipline dimension assurance dimension other dimension and subscribers satisfaction (Upal, 2008)..

\section{Customer Loyalty}

Customer loyalty is frequently examined from a behavioral point of view by measuring items such as amount of recurrence purchases, "share of wallet" and purchase frequency. A common statement is that loyalty translates into an unspecified amount of repeat procurements from the similar supplier over a particular period (Egan, 2004). Oliver (1999) defined loyalty as "An intensely held ability to re-buy or re-patronize a ch osen product/service persistently in the future, thereby causing repetitive samebrand purchasing, in spite of situational influences and marketing efforts having the potential to cause switching behavior". However, the description of loyalty based solely on repurchase behavior doesn't provide a holistic view of this intricate concept. This drove researchers to put forward alternative and more complete definitions.
Dick and Basu (1994) suggested that loyalty has evenly attitudinal and behavioral fundamentals and argued that it is determined by the strong point of the relationship between relative attitude and repeat support. Exploratory loyalty under the attitudinal lens, it $\mathrm{c}$ an be resulting from psychological contribution, judgment and a sense of concern towards a particular product or service (Oh, 1995 cited by Kim et al., 2004).In general, even though the fact that there are plenty of dissimilar approaches aiming at the definition and conceptualization of loyalty, there is a universal meeting towards the view that both behavioral and attitudinal features must be built-in. The behavioral view is usually based on the monitoring of the occurrence of frequent purchases and brand switches, while the attitudinal approach assumes that loyalty is resulting from psychological involvement and preference and focuses on issues such as brand recommendation, confrontation to better products, repurchase intent and willingness to pay a price best (Cronin and Taylor, 1992).

\section{E. Relationship between Service Quality and Customer Loyalty}

Three parameters of service quality; reliability, empathy and service Quality was found positively correlated (Siddiqui, 2011). Positive relationship was found between all the attributes of service quality attributes and customer loyalty with mediating effect of customer satisfaction in a study in retail banking sector in Bangladesh. Tangibles, responsiveness and reliability were found directly related with customer loyalty in Telecommunication industry in Ghana in the study of Iddrisu (2011) consistent with the result of Kheng, Lo Liang, Osman, Ramayah, Rahim (2010). Empathy had highest positive correlation while assurance had least correlation with customer loyalty. In a study conducted by Mensah and Kilika (2013) in Kenyan mobile telecommunication sector, all the indicators of service quality (of SERVQUAL) model found to have positive correlation with customer loyalty. Empathy has the highest influence on customer loyalty. Impact of all the parameters of customers ${ }^{\text {ee }}$ perceived service quality was positive on customer loyalty except tangibility in the study of Hassan, Malik Ayaz, Imran, Hussain and Javaria (2013). All the five constructs of SERVQUAL was found strongly connected with customer loyalty in the study of Poku, Ansah, Lamptey (2014) in the Telecommunication industry of Ghana.

\section{RESEARCH MODEL}

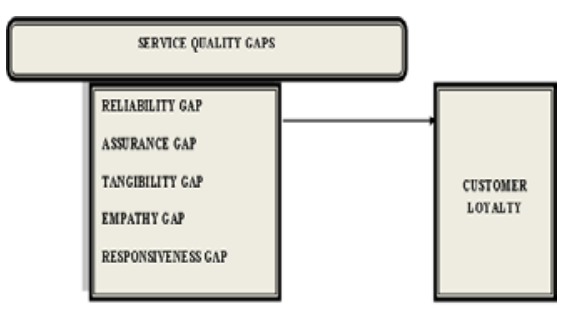

Fig. 1 Conceptual Model of the study 


\section{RESEARCH METHODOLOGY}

To study Customer Service Quality expectations and perception in Telecom sector in Jammu and Kashmir, a questionnaire survey was conducted. The basic issues concerning the study's research design and methodology are discussed as:

\section{A. Objectives of the Study}

The proposed study attempts to attain the following objectives:

1. To make comparison of customer service quality expectations and perceptions viz av iz Airtel and BSNL;

2. To examine influence of various service quality dimensions on customer loyalty; and

3. To suggest measures for enhancing customer loyalty of service users.

\section{B. Hypotheses of the study}

This study intends to test the following hypotheses:

$H_{1}$ : Service quality has positive and significant impact on customer loyalty.

$H_{1 a}$ : Reliability will have positive effect on customer loyalty.

$H_{1 b}$ : Assurance will have positive effect on customer loyalty.

$H_{1 c}$ : Tangibles will have positive effect on customer loyalty.

$H_{1 d}$ : Empathy will have positive effect on customer loyalty.

$H_{1 e}$ : Responsiveness will have positive effect on customer loyalty.

\section{Sample}

The selection of the sample was governed by the principles of proportionate Simple Random sampling, whereby, the four respondent categories- students, retailers and Government and Private office customers were taken one by one. After classifying each of the categories into various subgroups, care was taken that the number of items/respondents from each stratum is proportionate to the size of the stratum in relation to total population. Estimates of population based on the proportionate stratified sampling usually have greater precision (or smaller sampling error) than if, the whole populations were sampled by simple random sampling.

\section{Data Collection}

Survey method was adopted for collection of data and the survey instrument was hand distributed among the students, retailers, government and private officials in all the five districts of Kashmir division, the students, retailers, Government employees as well as private employees who are subscribers of BSNL and Airtel were contacted, who in turn proved instrumental in assembling the sample requirements already conveyed to them.
In addition, the secondary data has been obtained from the file records of the constituent telecom departments, website of BSNL and Airtel, outlets of BSNL and Airtel, retailers, journals, books, past research done in the field, and other relevant sources.

\section{E. The Research Instrument}

Most of the instruments were either adopted from previous published works or developed specifically for the present study. The Lickert's five-point scale is used throughout the study. The instruments used in this study for various constructs are explained as:

Service Quality dimension: The investigation involved modification of SERVQUAL, originally developed by Parasuraman, Zeithaml and Berry (1985). In related studies of market dimension, SERVQUAL consisting of $22 \mathrm{i}$ tem scale is the most widely accepted and mostly used scale as it encompasses the dimensions of service quality Reliability, Assurance, Tangibility, Empathy and Responsiveness.

TABLE I INTER-DIMENSION CORRELATIONS AND CRONBACH'S ALPHA VALUES

\begin{tabular}{|l|c|c|c|c|c|c|}
\hline \multicolumn{1}{|c|}{ Constructs } & $\mathbf{1}$ & $\mathbf{2}$ & $\mathbf{3}$ & $\mathbf{4}$ & $\mathbf{5}$ & $\mathbf{6}$ \\
\hline Tangibility & 1.00 & & & & & \\
\hline Reliability & 0.41 & 1.00 & & & & \\
\hline Responsiveness & 0.36 & 0.34 & 1.00 & & & \\
\hline Assurance & 0.39 & 0.41 & 0.41 & 1.00 & & \\
\hline Empathy & 0.34 & 0.40 & 0.39 & 0.42 & 1.00 & \\
\hline Customer Loyalty & 0.29 & 0.31 & 0.28 & 0.33 & 0.26 & 1.00 \\
\hline Cronbach's Alpha & 0.71 & 0.73 & 0.68 & 0.79 & 0.81 & 0.73 \\
\hline \multicolumn{7}{|c|}{ Source: Data compilation by the scholar for the present study }
\end{tabular}

Questionnaire was developed for customers using BSNL and Airtel service Provider. The items with respect to various dimensions were jumbled and arranged in a random order. As the main unit of analysis was the customer, all the twenty-two (22) items of service quality and five (5) items pertaining to customer loyalty were included in questionnaire. The respondents were as such asked to respond twenty-two (22) items dealing with customer expectations and perceptions, (5) items dealing with customer loyalty. Customer loyalty scale of Kaur and Soch (2012) was adapted for the present study. Further, reliability was tested by Cronbach's alpha values. Table I shows the reliability and Inter-dimension correlations. The Cronbach's Alpha values (table 1) are also satisfactory, thereby, reflecting that the items imposed on a particular construct are consistently measuring that particular construct.

\section{ANALYSIS AND INTERPRETATION}

From a comparative point of view (table II), the gaps across dimensions of service quality of BSNL is highest in empathy (-41.8\%), and lowest in assurance $(-22.0 \%)$, 
Further in Airtel empathy has highest gap (-30.2\%), which indicates that there is a substantial and significant gap between service quality gap of BSNL and Airtel in area of empathy. However, Airtel is doing very well in other dimensions of services.

TABLE II A COMPARISON OF SERVICE QUALITY GAPS BETWEEN BSNL \& AIRTEL

\begin{tabular}{|c|c|c|c|}
\hline S. No. & $\begin{array}{l}\text { Perception- } \\
\text { Expectation } \\
\text { (Gaps across } \\
\text { dimensions) }\end{array}$ & $\begin{array}{c}\text { BSNL in } \\
\text { \%age }\end{array}$ & $\begin{array}{c}\text { Airtel in } \\
\text { \%age }\end{array}$ \\
\hline (1) & (2) & (3) & (4) \\
\hline 1 & Reliability & -25.20 & $(+) 12$ \\
\hline 2 & Assurance & -22.0 & $(+) 7.6$ \\
\hline 3 & Tangibility & -36.0 & $(+) 15.6$ \\
\hline 4 & Empathy & -41.8 & $(-) 30.2$ \\
\hline 5 & Responsiveness & -36.2 & $(+) 2.2$ \\
\hline
\end{tabular}

The results given in table III clearly indicate that the customer loyalty is significantly predicted by the service quality $(\beta=.434 ; p<.001)$. Further, the dimensions of the service quality (reliabilty, assurance, tangibility, empathy and responsiveness) also have a significant positive influence on customer loyalty.

TABLE III SERVICE QUALITY AND CUSTOMER LOYALTY

\begin{tabular}{|c|c|}
\hline Variable & Customer Loyalty \\
\hline Service Quality & $.434^{* *}$ \\
\hline
\end{tabular}
Source: Survey Data Collected by the scholar for the study.
Note $:(* *=<0.01)$.

Of the five dimensions in the service quality, empathy $(\beta=$ $.49 ; p<.01)$ is the most influential predictor of customer loyalty followed by responsiveness $(\beta=.42 ; p<.01)$, assurance $(\beta=.38 ; p<.01)$, reliability $(\beta=.35 ; p<.05)$ and tangibility $(\beta=.24 ; p<.05)$ (table 7$)$.

TABLE IV COEFFICIENTS USING PATH ANALYSIS BETWEEN SERVICE QUALITY GAPS AND CUSTOMER LOYALTY

\begin{tabular}{|c|c|}
\hline $\begin{array}{c}\text { Service Quality } \\
\text { Gap Dimensions }\end{array}$ & $\begin{array}{c}\text { Customer } \\
\text { Loyalty }\end{array}$ \\
\hline Reliability & $0.35^{*}$ \\
\hline Assurance & $0.38^{* *}$ \\
\hline Tangibility & $0.24^{*}$ \\
\hline Empathy & $0.49^{* *}$ \\
\hline Responsiveness & $0.42^{* *}$ \\
\hline $\mathrm{R}^{2}$ & 0.47 \\
\hline
\end{tabular}

It is also clearly evident from table 7 that the five components in service quality (reliabilty, assurance, tangibility, empathy and responsiveness) collectively explain $47 \%$ of the variance in customer loyalty $\left(\mathrm{R}^{2}=.47\right)$. Thus, it is proved service quality positively and significantly influences customer loyalty.

\section{DISCUSSION AND CONCLUSION}

The study was conducted to examine the impact of service quality on customer loyalty. The study thoroughly examined the impact of each antecedent of service quality on customer loyalty through SERVQUAL model of Persuraman et. al, (1988). The result showed a positive impact of service quality on customer loyalty. The result coincides with Poku et. al. (2014).

The primary findings of this study indicate that there exists a significant gap between the expectations and perceptions of customers regarding the quality of service provided by the telecom operators under study. This gap is wider in BSNL as compared to Airtel. Further, the results indicate the impact of service quality dimensions (reliability, assurance, tangibility, empathy, and responsiveness) on customer loyalty. Of the five dimensions in the service quality, empathy is the most influential predictor of customer loyalty followed by responsiveness, assurance, reliability and tangibility.

A comparison between Airtel and BSNL on the service quality dimensions reveals that BSNL is substantially lagging behind Airtel. Out of the five service quality dimensions, BSNL has achieved less than average score on all the five dimensions (less than three on a five point scale) while as Airtel recorded below average performance only on one dimension (empathy). The other four dimensions showed above average performance (greater than three on a five point scale). The above discussion leads us to infer that Airtel is vastly outperforming BSNL in terms of the quality of service delivered to customers. Therefore, BSNL authorities are required to pay earnest attention to explore the reasons for showing below average performance and take necessary measures to rectify them.

\section{SUGGESTIONS}

1. The results of present study indicate that the telecom service providers should focus more on enhancing the physical facilities of its business units. This includes the use of up-to-date equipment which is laid out in a manner that is in coherence with the kind of service being delivered. This will create a s ense of belongingness amongst the customers towards the service provider and, consequently, may help in creating and maintaining a loyal customer base.

2. Market research groups should be established that will constantly monitor the needs and requirements of customers and communicate the same to other departments of the organization. The design and development of new products should be strictly based on such inputs from the research wing. 
3. Constant surveys must be undertaken so as to ascertain the expectations of customers about the service performance. Those expectations need to be translated into the service performance standards and, subsequently, communicated across all levels of organizational hierarchy. Specifically, strong communication channels must be established with the front line employees so that they are fully aware of the customer expectations of service performance.

4. The management should lay more emphasis on customer orientation of employees. Personal attention must be provided by employees to the customers so as to result in an improved positive service experience. Further, better customer outcomes can be achieved if the behavioral aspect of employee job performance is supplemented by the technical knowledge as well i.e. the employees must be fully aware of the needs of customers. Employee training can serve as an effective tool for achieving this purpose. Moreover, the employee recruitment and selection mechanism must also be designed in a way that equally emphasizes the behavioral and technical aspect of employee job performance, especially of those involved in customer contact. This can considerably reduce the service quality gaps so identified in this study.

5. Increased attention needs to be paid by the managers towards emphasizing the importance of employee courtesy in determining the service quality perception of customers. Particularly, contact employees must be trained to give customers an impression of their willingness to serve them by providing them individual attention.

6. The results of present study indicate that there is lack of prompt responsiveness on part of employees in responding to customer requests. It may, perhaps, be an outcome of overburdened work requirements for employees that hinders rapid service delivery. Given the significance of speed of service delivery in determining the customer service quality perception, it is suggested that additional managerial focus should be put on enhancing the rapidness of service delivery.

\section{LIMITATIONS AND FUTURE RESEARCH}

First, the data for present study came only from the state of Jammu and Kashmir and that too from only the telecom sector which, therefore, may raise concerns about the generalization of results. It is, therefore, required that similar research may be replicated in other geographical areas covering different sectors of an economy. Second, all the key performance indicators in present study are measured subjectively (using a questionnaire). Therefore, the shortcomings inherent in every questionnaire based survey where answers are dependent on respondents' perception could not be overcome. Also, investigation into the antecedents of service quality should be included as the subject matter of future research.

\section{REFERENCES}

[1] Parasuraman, V. Zeithaml and L. Berry, "SERVQUAL: A Multiple Item Scale For Measuring Consumer Perceptions of Service Quality", Journal Of Retailing, Vol.64, No. 1, pp. 12-40 ,1988.

[2] H. Kaur and H. Soch, "Validating antecedents of customer loyalty for Indian cell phone users." Vikalpa, Vol. 37 No.4, pp. 47-62, 2012.

[3] V. Zeithaml and M. Bitner,'Services Marketing". (3rd Edition).New York: McGraw-Hill, 2003.

[4] Lovelock, "Classifying Services to Gain Strategic Marketing Insights" Journal of Marketing, Vol. 3, 1983.

[5] T. Panda, "Creating Customer Lifetime Value through Effective CRM in Financial Services Industry", Journal of Services Research, Vol. (2), 1, pp. 57-71, 2003.

[6] Lymperopoulos, I. Chaniotakis and M. Soureli, "The Importance of Service Quality in Bank Selection for Mortgage Loans" Managing Service Quality, Vol.16, No.4, pp. 365-379, 2006.

[7] S. Kushwah and A. Bhargava, "Service Quality Perception of Telecom Sector In India" International Journal of Advancement in Technology, Vol. 5, No. 15 ,pp.1-10, 2014.

[8] Parasuraman, V. Zeithaml and L. Berry, "A Conceptual Model of Service Quality And Its Implications For Future Research," Journal Of Marketing, Vol.49, pp. 41-50, 1985.

[9] J. Cronin, S. Taylor, "Measuring service quality a reexamination and extension", The journal of Marketing, pp. No. 55-68, 1992.

[10] Gronroos, "An applied service marketing theory". European Journal of Marketing, Vol. 16,No.7, pp.30-41, 1982

[11] Parasuraman, L. Berry and V. Zeithaml, "Perceived service quality as a Customer-based performance measure: An empirical examination of organizational barriers using an extended service quality model". Human Resource Management, Vol. 30, No. 3, pp. 335-364, 1991.

[12] V. Zeithaml and L. Berry, SERVQUAL: "A multiple item scale for measuring customer perception of service quality", Journal of Retailing, 64, (spring),pp. 12-37, 1988.

[13] R. Bolton and J. Drew, "Mitigating the effect of service encounters", Marketing letters, Vol. 3(1), pp. 57-70, 1992.

[14] Parasuraman, V. Zeithaml and L. Berry, "A conceptual model of service quality and its implications for future research", journal of Marketing, Vol. 49, fall, pp. 41-50, 1988.

[15] J. Cronin and S. Taylor, "Measuring service quality: a reexamination and extension". The Journal of Marketing, pp. 55-68, 1992.

[16] V. Zeithaml, "Consumer perceptions of price, quality and value: A means -end model and synthesis of evidence." The Journal of Marketing, pp. 2-22, 1988.

[17] V. Zeithaml, A. Parauraman and L. Berry, "Problems and strategies in service marketing." The Journal of Marketing, pp. 33-46, 1985.

[18] V. Zeithaml, L. Berry and A. Parasuraman, "Communication and control processes in the delivery of service quality." The journal of Marketing, pp.35-48, 1988.

[19] L. Berry, A. Parasuraman, V. Zeithaml and D. Adsit, "Improving service quality in America: lessons learned", The Academy of Management Executive, Vol 8, May, pp. 32-53, 1994.

[20] S. Alnsour, A. Tayeh and M. Alzyadat, "Using SERVQUAL to assess the quality of service provided by Jordanian telecommunications sector." International journal of commerce and management, Vol. 24,No.3, pp. 209-218, 2014.

[21] Santouridis and P. Trivellas, "Investigating the impact of service quality and customer satisfaction on customer loyalty in mobile telephony in Greece. The TQM journal, Vol. 22, No.3, pp. 330-343, 2010.

[22] Y. Kuo, C. Wu and W. Deng, "The relationships among service quality, perceived value, customer satisfaction, and post purchase intention in mobile value- added services." Computers in human behavior, Vol. 25,No. 4, pp. 887-896, 2009.

[23] T. Lai, "Service quality and perceived value's impact on satisfaction, intention and usage of short message service (SMS)". Information system frontiers, Vol. 6, No.4, pp. 353-368, 2004.

[24] W. Johnson and A. Sirikit, "Service quality in Thai telecommunication industry: A tool for achieving a sustainable competitive advantage." Management Decision, Vol 40, No.7, pp. 693-701, 2002.

[25] M. Upal and B. Dhaka, "Telecommunication service gap: Call center service quality perception and satisfaction. Journal of Communications of the IBIMA, Vol. 3, pp. 18-27, 2008. 
[26] Egan, "Relationship Marketing: Exploring Relational Strategies in Marketing". Pearson Education, Harlow, 2004.

[27] R. Oliver, "Whence consumer loyalty"? The Journal of Marketing, pp. 33-44, 1999.

[28] Dick and K. Basu, "Customer loyalty: toward an integrated conceptual framework." Journal of the Academy of Marketing Science, Vol. 22, No.2, pp. 99-113, 1994.

[29] H. Oh, "An empirical study of the relationship between restaurant image and customer loyalty (Doctoral dissertation)", 1995.

[30] M. Kim, M. Park and D. Jeong, "The effects of customer satisfaction and switching barrier on customer loyalty in Korean mobile telecommunication services." Telecommunications Policy, Vol. 28, No.2, pp. 145-159, 2004.

[31] Siddiqui and Kaziomar, "Interrelation between Service Quality Attributes, Customer Satisfaction and Customer Loyalty in the Retail Banking Sector in Bangladesh" International Journal Of Business And Management, Vol.6, No. 3 March pp. 12-36, 2011

[32] Iddrisu, "Service Quality and Customer Loyalty: "The Case of the Mobile Telecommunication Industry in Ghana", Award of
Commonwealth Executive Masters in Business Administration (CEMBA), Kwame Nkrumah University of Science and Technology, 2011.

[33] Liang, M. Osman, T. Ramayah and M. Rahim, "The Impact of Service Quality on Customer Loyalty: A Study of Banks in Penang, Malaysia", International Journal of Marketing Studies, Vol. 2, No. 2, 2010.

[34] J. Kilika Mensah, "The Relationship between Service Quality and Customer Loyalty in the Kenyan Mobile Telecommunication Service Industry", European Journal of Business and Management, Vol. 5, No. 23, pp. 26-36, 2013.

[35] Hassan, A. Malik, M. Imran, A. Hussain and A. Javaria, "Relationship Among Customers" Perceived Service Quality, Satisfaction and Loyalty in the Retail Banking Sector of Pakistan" World Applied Science Journal Vol. 24, No.8, pp. 1020-1030, 2013.

[36] K. Poku, M. Ansah and D. Lamptey, "The Impact of Service Quality Delivery on Customer Loyalty in the Telecommunication Industry: A Case Study of Expresso Telecom, Ghana", Journal of Research in Marketing, Vol. 3 No.1,August, 2014. 